\title{
Comparison of fasting and postprandial levels of commonly used biochemical and hematological parameters
}

\author{
Sık kullanılan biyokimyasal ve hematolojik parametrelerin açlık ve postprandiyal \\ düzeylerinin karşılaştırılması
}

\author{
Elif Turan ${ }^{1}$, Recep Tunç ${ }^{2}$, Yaşar Turan ${ }^{3}$
}

\section{Abstract}

Aim: Physicians and patients may have varying preferences for optimal blood analysis time. We aimed to determine the tendency for the optimal blood analysis time of the physicians and patients and also to determine the difference in some commonly used biochemical and hematological parameters, between fasting and food intake.

Methods: Questionnaire and cross-sectional designs were used. The doctors and patients were conducted to a survey about the appropriate time for blood tests before the study. 112 patients were included in study. Blood samples were collected after 8-10 hours of fasting and 2 hours after 600-700 calories lunch. Blood creatinine, alanine aminotransferase, sodium, glucose, calcium, albumin, total cholesterol, triglyceride, HDL, LDL, alkaline phosphatase, total bilirubin, lactate dehydrogenase, complete blood count, erythrocyte sedimentation rate prothrombin time and TSH were studied and the values were compared.

Results: In our survey, $75 \%$ of patients (54 patients in the outpatient clinic and 98 patients in the blood collection unit, a total of 152) and $77 \%$ of doctors were thinking that fasting was the appropriate time for blood tests. There were significant increase in glucose $(\mathrm{p}<0.01)$, triglyceride $(\mathrm{p}<0.01)$ and platelets $(\mathrm{p}=0.035)$ and significant decrease in sodium $(\mathrm{p}=0.01)$ after the food intake. There was no statistically significant difference in the other parameters.

Conclusion: The majority of physicians and patients had the opinion that blood tests should be given in fasting Although there were significant differences in glucose, triglyceride, thrombocyte and sodium levels in our study, thrombocyte and sodium differences may not exhibit any clinical importance. Notwithstanding, high postprandial levels of glucose and triglyceride are valuable indicators for cardiovascular disease and diabetes risk

Keywords: fasting, food intake, glucose, triglyceride.

Öz

Amaç: Hekimler ve hastaların kan tahlili verme zamanı tercihleri değişiklik gösterebilmektedir. Çalışmamızda anketler ile hekim ve hastaların eğilimlerini belirlemeyi ve günümüzde sık kullanılan bazı biyokimyasal ve hematolojik tetkiklerde açlık ve tokluk arasında farklılık olup olmadığını tespit etmeyi amaçladık.

Materyal-metod: Anket ve kesitsel dizayn birlikte kullanıldı. Çalışmaya başlamadan önce doktorlara ve hastalara kan tahlilleri için uygun kan verme zamanı konusunda anket yapıldı. Çalışmaya toplam 112 hasta alındı. Bu hastalarda 8-10 saatlik açlık sonrası ve 600-700 kalorilik öğle yemeğinden 2 saat sonra kan alındı. Alınan kanlardan kreatinin, alanin aminotransferaz, sodyum, glukoz, kalsiyum, albumin, total kolesterol, trigliserid, HDL, LDL, alkalen fosfataz, total bilirubin, laktat dehidrogenaz, hemogram, sedimentasyon, protrombiz zamanı ve TSH çalıșıldı ve değerleri karșılaștırıldı.

Bulgular: Çalışmamızın anket evresinde; hastaların \%75'i (54 poliklinik hastası ve 98 kan alma birimine gelen hasta olmak üzere toplam 152), doktorların \% 77'si tetkiklerin aç karna yapılması gerektiğini düşünmekteydiler Çalışılan kanların sonucunda glukoz $(p<0.01)$, trigliserid $(p<0.01)$ ve trombositlerde $(p=0.035)$ toklukta istatistiksel olarak anlamlı artış, sodyumda $(\mathrm{p}=0.01)$ ise toklukta anlamlı azalma tespit edildi. Diğer parametrelerde açlık ve tokluk arasında istatistiksel olarak anlamlı farklılık bulunmadı.

Sonuç: Doktor ve hastaların büyük çoğunluğu kan tetkiklerinin açlıkta verilmesi gerektiği görüşündedir Çalışmamızda glukoz, trigliserid, trombosit ve sodyumda anlamlı farklılık tespit edilse de, trombosit ve sodyum düzeyindeki farklılık klinik önem arzetmeyecek seviyelerdeydi. Toklukta tespit edilen yüksek glukoz ve trigliserid düzeyleri kardiovasküler hastalık ve diyabet riski için kıymetli göstergelerdir.
1 Bozok University, The School of Medicine, Department of Endocrinology, Yozgat, Turkey.

${ }^{2}$ Necmettin Erbakan University, The School of Medicine, Department of Romotology,Konya, Turkey.

3 Bozok University, The School of Medicine, Department of Cardiology, Yozgat, Turkey.

Ethics Committee Approval: The study wass approved by the local ethical authority (No. 2008/207).

Etik Kurul Onayı: Çalışma lokal etik komite tarafından onaylanmıștır (No. 2008/207)

Conflict of Interest: No conflict of interest was declared by the authors.

Çıkar Çatışması: Yazarlar çıkar çatışması bildirmemişlerdir.

Financial Disclosure: The authors declared that this study has received no financial support. Finansal Destek: Yazarlar bu çalıșma için finansal destek almadıklarını beyan etmișlerdir.

Geliş Tarihi / Received: 19.03.2019 Kabul Tarihi / Accepted: 28.05.2019 Yayın Tarihi / Published: 01.08.2019

Sorumlu yazar / Corresponding author

Elif Turan

Bozok University, School of Medicine, Department of Endocrinology, Yozgat, Turkey.

Postal code: 66040

e-posta: drelifturan@hotmail.com Tel/Phone: +9003542127050

Copyright (C) ACEM 


\section{Introduction}

Laboratory test results can be affected by various controllable factors such as alcohol use, smoking, physical activity, and diet as well as fasting state before blood collection. Patients must be informed about how to prepare before a laboratory test [1]. The Clinical and Laboratory Standards Institute (CLSI) recommends verification of dietary restrictions, as certain tests may require fasting [2]. In the Mayo Clinic website, it is stated that fasting is not required, only if complete blood count test is to be performed [3].

In addition, there is no consensus among physicians and patients as to whether dietary restriction is required before blood collection. A debate still exists regarding some particular tests. Although recent studies have made suggestions regarding the testing conditions of lipids, it is still unclear for other tests [4-7]. On the other hand, patients with a chronic condition such as hypertension and diabetes mellitus (DM) skip their medications or face such risks as hypoglycemia for the sake of having their fasting blood tests done.

In the present study, we aimed to determine the tendency of the physicians and patients for the optimal blood analysis time, with simple questionnaires. We also aimed to evaluate whether commonly used biochemical and hematological parameters were affected by dietary restrictions.

\section{Material and methods}

The study protocol was approved as a thesis by the Ethics Committee of Necmettin Erbakan University, Faculty of Medicine, Konya, Turkey (No. 2008/207). A written informed consent was obtained from each participant. The study was conducted in accordance with the principles of the Declaration of Helsinki [9], as revised in 1975 and 1983.

The study included five stages as shown in Figure 1.

ALGORITHM OF THE STUDY

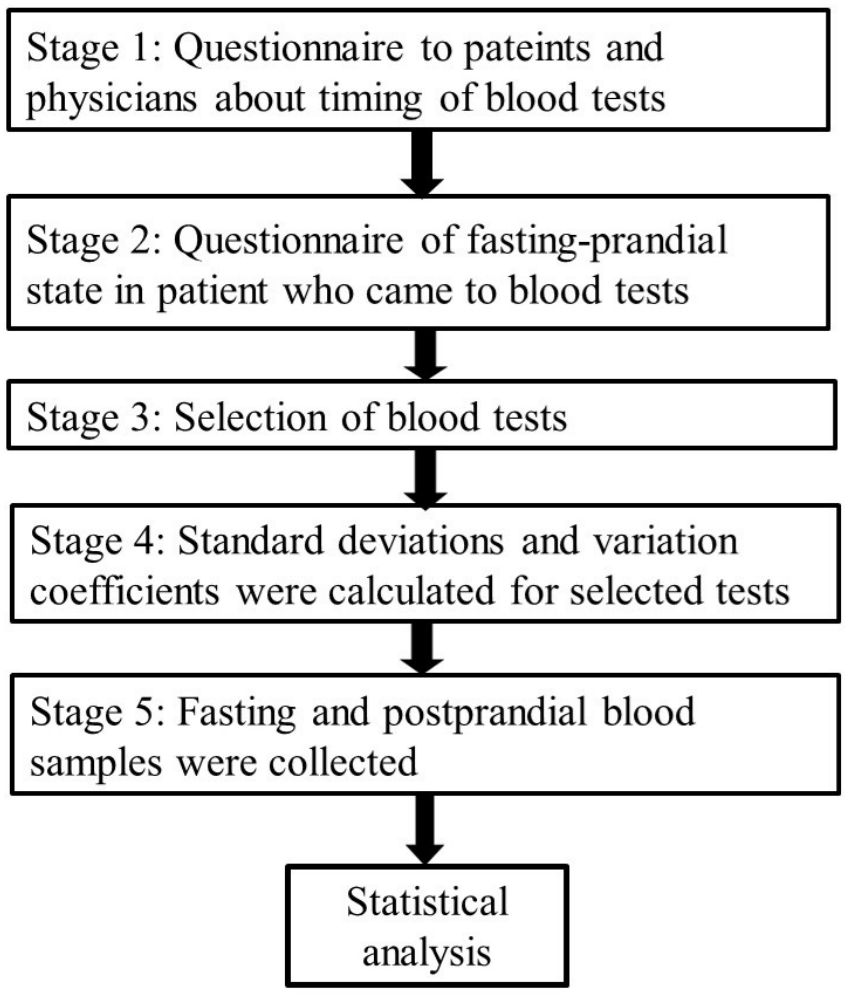

Figure 1: Algorithm of the study

First stage: In the first stage, a questionnaire was administered to patients and physicians to evaluate their attitudes toward the timing of blood tests. The questionnaire administered to 54 patients attending to the internal medicine outpatient clinics contained two options as fasting and postprandial. Forty (74\%) of them thought that fasting was appropriate for blood testing. and the questionnaire administered to 57 physicians consisted of attending physicians, residents, and intern physicians with three options as fasting, postprandial, and at any time of the day and $44(77 \%)$ of them preferred their patients to have their tests done in the fasting (Table 1).

Table 1: Results of the surveys.

The patient group comprised of 54 patients (attended outpatient clinics)

At what time of the day would it be appropriate to have blood tests?

$\begin{array}{ll}\text { Morning fasting } & 40(74 \%) \\ \text { Morning postprandial } & 14(26 \%)\end{array}$

A total of 98 patients attending for blood collection were asked:

Are you in fasting state?

$\begin{array}{ll}\text { Yes } & 75(76 \%) \\ \text { No } & 23(24 \%)\end{array}$

Do you have Diabetes Mellitus?

Yes $19(19.3 \%)$

No

$79(80.7 \%)$

Do you have regular medications?

$$
\begin{aligned}
& \text { Yes } \\
& \text { No }
\end{aligned}
$$

If yes, have you taken your medication? Yes

No

$45(74 \%)$

Of physicians including residents, interns, and attending physicians 57 responded to this question:

In what state do you prefer your patients to have their tests done?

$\begin{array}{ll}\text { Morning fasting } & 44(77 \%) \\ \text { Postprandial } & 2(4 \%) \\ \text { At any time of the day } & 11(19 \%)\end{array}$

Second stage: A questionnaire was administered to 98 patients who were admitted to the blood collection unit of Necmettin Erbakan University, Faculty of Medicine. This questionnaire inquired dietary restrictions, presence of chronic diseases, and medications used (Table 1). Seventy-five (76\%) of 98 patients who were admitted to the blood collection unit were in a fasting state. Although 61 of them were using regular medications, 45 patients $(74 \%)$ attended the unit without taking their medicines.

Third stage: This stage involves the selection of blood tests to be performed for the study. For this purpose, the number of tests performed in the biochemistry and hematology laboratories within the last month was examined. A total of 22 frequently performed tests were selected all of which have clinical importance and performed more than 1,000 within the last month.

Fourth stage: We questioned the reliability of our laboratory by working the same blood sample repetitively. For this purpose, blood samples were collected from a healthy volunteer. Blood samples of this volunteer were divided into 10 tubes. The test tubes were sent to the laboratory for the repetitive analysis. Coefficient variation (CV) is one of the methods used for the validity of the method [8]. Method validity is a process 
that is performed to obtain the same result every time. In order to evaluate the safety of our blood test results, we calculated the CV and standard deviation (Table 2).

Table 2: Standard deviation and coefficient variation of the study parameters calculated from the blood samples of a healthy volunteer.

\begin{tabular}{|c|c|c|c|}
\hline & Mean & SD & $\mathrm{CV} \%$ \\
\hline Glucose (mg/dL) & 85.60 & 3.534 & 4.12 \\
\hline Creatinine (mg/dL) & 0.883 & 0.04448 & 5 \\
\hline Sodium $(\mathrm{mEq} / \mathrm{L})$ & 144.5 & 2.068 & 1.43 \\
\hline Calcium (mg/dL) & 9.90 & 0.2025 & 0.204 \\
\hline Uric acid (mg/dl) & 3.54 & 0.0972 & 0.27 \\
\hline ALT (U/L) & 41.40 & 0.51 & 1.23 \\
\hline Albumin (mg/dL) & 4.590 & 0.0568 & 1.23 \\
\hline Total bilirubin (mg/dL) & 0.720 & 0.0422 & 5.8 \\
\hline Alkaline phosphatase (U/L) & 86.3 & 1.889 & 2.18 \\
\hline Lactate dehydrogenase (U/L) & 204 & 5.793 & 2.83 \\
\hline Total cholesterol (mg/dL) & 248 & 3.859 & 1.55 \\
\hline Triglyceride (mg/dL) & 171.90 & 1.792 & 1.04 \\
\hline HDL (mg/dL) & 51.20 & 1.317 & 2.5 \\
\hline LDL (mg/dL) & 162.5 & 4.062 & 2.4 \\
\hline TSH (mIU/L) & 2.9306 & 0.0556 & 1.89 \\
\hline Prothrombin time (sec) & 1.05 & 0.0867 & 8.25 \\
\hline $\operatorname{ESR}(\mathrm{mm} / \mathrm{h})$ & 31 & 5.292 & 17 \\
\hline Leukocyte (x1097/L) & 5.620 & 0.0789 & 1.48 \\
\hline Hemoglobin $(\mathrm{g} / \mathrm{dL})$ & 16 & 0.05 & 1.01 \\
\hline MCV (fL) & 86.80 & 0.422 & 0.4 \\
\hline $\mathrm{MCH}(\mathrm{fL})$ & 18.78 & 3.129 & 16.66 \\
\hline Platelet $\left(\times 10^{9} / \mathrm{L}\right)$ & 285.20 & 6.233 & 2.1 \\
\hline
\end{tabular}

CV: coefficient of variation, SD: standard deviation, ALT: alanine aminotransferase, HDL: High-density lipoprotein, LDL: low-density lipoprotein, TSH: thyroid stimulating hormone, ESR: erythrocyte sedimentation rate, MCV: mean corpuscular volume, MCH: mean corpuscular hemoglobin.

Fifth stage: A total of 128 patients who were hospitalized in the nephrology, gastroenterology, endocrinology and rheumatology clinics of the Department of Internal Medicine of Necmettin Erbakan University, Faculty of Medicine and who agreed to participate in the study. Hospitalized patients were preferred to minimize the difference of the calorie intake between the patients. During this period, the patients were consecutively enrolled in the study. Patients with poor oral intake and poor general condition and significant anemia were excluded. In total, 112 patients were included in the study. Among the patients, 37 had hypertension, 29 had diabetes, 17 had chronic renal failure (CRF), and 11 had liver failure. Blood samples from patients with CRF were collected on days off from dialysis.

Fasting blood samples in the morning (after an 8 to 10 -h fasting) and postprandial blood samples at two hours with a 600700 calorie diet were collected from a total of 112 patients for hematological and biochemical tests [glucose $(\mathrm{mg} / \mathrm{dL})$, creatinine $(\mathrm{mg} / \mathrm{dL})$, sodium $(\mathrm{mEq} / \mathrm{L})$, calcium $(\mathrm{mg} / \mathrm{dL})$, uric acid $(\mathrm{mg} / \mathrm{dL})$, alanine aminotransferase (ALT) (U/L), albumin $(\mathrm{mg} / \mathrm{dL})$, total bilirubin (mg/dL), alkaline phosphatase (U/L), lactate dehydrogenase (U/L), total cholesterol $(\mathrm{mg} / \mathrm{dL})$, triglyceride (mg/dL), high-density lipoprotein (HDL) (mg/dL), low-density lipoprotein (LDL) (mg/dL), thyroid-stimulating hormone (TSH) (mIU/L), prothrombin time (PT) (sec), erythrocyte sedimentation rate $(\mathrm{ESR})(\mathrm{mm} / \mathrm{h})$, leucocyte count $(\mathrm{x} 109 / \mathrm{L})$, hemoglobin $(\mathrm{g} / \mathrm{dL})$, mean corpuscular volume (MCV) (fL), mean corpuscular hemoglobin $(\mathrm{MCH})(\mathrm{fL})$, platelet count (x109/L)]. The tests were performed on fresh blood samples without storage using standard methods.

\section{Statistical Analysis}

Statistical analysis was performed using the SPSS for Windows version 18.0 software (SPSS Inc., Chicago, IL, USA). Descriptive statistics were expressed in mean, standard deviation (SD), and number and percentage. The paired sample test was used to analyze significant differences between the two groups. The questionnaires administered to the physicians and patients were analyzed using the chi-square test. A p value of $<0.05$ was considered statistically significant.

CVs were calculated for 22 parameters examined in the study. When we calculated the $\mathrm{CV}$ for these 22 parameters, the $\mathrm{CV}$ of the parameters except total bilirubin, sedimentation rate, $\mathrm{MCH}$, and PT were found to be $\leq 5 \%$. This situation was regarded as the sufficient reliability and repeatability of these 18 parameters.

\section{Results}

Forty of 54 patients (74\%) attending to the general internal medicine outpatient clinics preferred fasting blood collection, whereas 44 of 57 physicians $(77 \%)$ including attending physicians, residents, and intern physicians found fasting blood collection to be appropriate for blood tests. There was no significant difference in the preferences of dietary restriction between the physicians and patients $(p=0.157)$. Seventy-five (76\%) of 98 patients who were admitted to the blood collection unit were in a fasting state. Although 61 of them were using regular medications, 45 patients $(74 \%)$ attended the unit without taking their medicines (Table 1). There was no significant difference in the ratio of fasting-postprandial state between patients who were on regular follow-up due to a chronic disease and those who did not have a chronic disease and presented to the clinic for the first time $(\mathrm{p}=0.157)$. Furthermore, there was no significant difference in the patient and physician survey results and the practices of the patients for blood collection $(\mathrm{p}=0.199)$.

Of a total of 112 participants, 67 were females and 45 were males with a mean age of $56.34 \pm 14.55$ years. The questionnaires administered to the patients and physicians and their results are presented in Table 1.

The $\mathrm{CV}$ was $\leq 5 \%$ for 18 parameters other than total bilirubin, ESR, MCH, and PT (Table 2).

Fasting and postprandial test results of 112 patients included in the final stage of the study are presented in Table 3. Compared to the results in the fasting state, postprandial glucose $\mathrm{mg} / \mathrm{dL}(107.68 \pm 28.70$ vs. $144.81 \pm 36.20, \mathrm{p}<0.01)$, triglycerides $\mathrm{mg} / \mathrm{dL}(149.49 \pm 21.78$ vs. $165.83 \pm 25.75, \mathrm{p}=0.006)$, and platelet count $\mathrm{g} / \mathrm{dL} \quad(251.55 \pm 32.5$ vs. $262.25 \pm 33.7, \mathrm{p}=0.035)$ were 
significantly higher, while sodium level $\mathrm{mEq} / \mathrm{L}(136.32 \pm 2.06$ vs. $135.25 \pm 1.94, \mathrm{p}=0.01)$ was significantly lower. The corrected sodium level was calculated in the patients with a glucose level above $125 \mathrm{mg} / \mathrm{dL}$ and the difference in the sodium levels remained statistically significant $(\mathrm{p}=0.02)$. However, there was no statistically significant difference between the fasting and postprandial levels of other parameters $(\mathrm{p}>0.05)$.

Table 3: Fasting and postprandial test results of 112 patients.

\begin{tabular}{lcc} 
Parameter & Fasting value & $\begin{array}{c}\text { Postprandial } \\
\text { value }\end{array}$ \\
\hline
\end{tabular}

\begin{tabular}{|c|c|c|c|}
\hline Age $(\text { year })^{\mu}$ & \multicolumn{2}{|c|}{$56.34 \pm 14.55$} & \\
\hline Gender (male/female) & \multicolumn{2}{|c|}{$45 / 67$} & \\
\hline Glucose $(\mathrm{mg} / \mathrm{dL})^{\mu}$ & $107.68 \pm 28.70$ & $144.81 \pm 36.20$ & $<0.01$ \\
\hline Creatinine $(\mathrm{mg} / \mathrm{dL})^{\mu}$ & $1.17 \pm 1.10$ & $1.32 \pm 1.09$ & 0.146 \\
\hline Sodium $(\mathrm{mEq} / \mathrm{L})^{\mu}$ & $136.32 \pm 2.06$ & $135.25 \pm 1.94$ & 0.010 \\
\hline Calcium $(\mathrm{mg} / \mathrm{dL})^{\mu}$ & $8.74 \pm 0.22$ & $8.67 \pm 0.24$ & 0.251 \\
\hline Uric acid $(\mathrm{mg} / \mathrm{dL})^{\mu}$ & $5.43 \pm 0.89$ & $5.47 \pm 0.82$ & 0.706 \\
\hline $\operatorname{ALT}(\mathrm{U} / \mathrm{L})^{\mu}$ & $40.56 \pm 1.77$ & $41.75 \pm 1.58$ & 0.589 \\
\hline Albumin $(\mathrm{mg} / \mathrm{dL})^{\mu}$ & $3.531 \pm 0.1$ & $3.74 \pm 0.09$ & 0.081 \\
\hline Total bilirubin $(\mathrm{mg} / \mathrm{dL})^{\mu}$ & $1.32 \pm 0.05$ & $1.23 \pm 0.05$ & 0.560 \\
\hline Alkaline phosphatase $(\mathrm{U} / \mathrm{L})^{\mu}$ & $88.56 \pm 1.78$ & $92.34 \pm 2.65$ & 0.121 \\
\hline Lactate dehydrogenase (U/L) ${ }^{\mu}$ & $261.29 \pm 6.74$ & $248.92 \pm 5.93$ & 0.082 \\
\hline Total cholesterol $(\mathrm{mg} / \mathrm{dL})^{\mu}$ & $166.29 \pm 34.26$ & $172.75 \pm 35.88$ & 0.512 \\
\hline Triglyceride $(\mathrm{mg} / \mathrm{dL})^{\mu}$ & $149.49 \pm 21.78$ & $165.83 \pm 25.75$ & 0.006 \\
\hline $\operatorname{HDL}(\mathrm{mg} / \mathrm{dL})^{\mu}$ & $32.24 \pm 8.28$ & $32.41 \pm 8.32$ & 0.809 \\
\hline $\mathrm{LDL}(\mathrm{mg} / \mathrm{dL})^{\mu}$ & $101.10 \pm 30.3$ & $98.68 \pm 33.3$ & 0.328 \\
\hline $\mathrm{TSH}(\mathrm{mIU} / \mathrm{L})^{\mu}$ & $2.69 \pm 0.4$ & $2.41 \pm 0.39$ & 0.174 \\
\hline Prothrombin time $(\mathrm{sec})^{\mu}$ & $1.145 \pm 0.02$ & $1.140 \pm 0.02$ & 0.726 \\
\hline $\operatorname{ESR}(\mathrm{mm} / \mathrm{h})^{\mu}$ & $34.42 \pm 11.21$ & $36.61 \pm 12.1$ & 0.082 \\
\hline Leukocyte $\left(\times 10^{9} / \mathrm{L}\right)^{\mu}$ & $9.71 \pm 0.92$ & $9.58 \pm 0.95$ & 0.105 \\
\hline Hemoglobin $(\mathrm{g} / \mathrm{dL})^{\mu}$ & $12.39 \pm 0.53$ & $12.40 \pm 0.57$ & 0.621 \\
\hline $\operatorname{MCV}(\mathrm{fL})^{\mu}$ & $82.71 \pm 3.15$ & $82.60 \pm 4.01$ & 0.902 \\
\hline $\mathrm{MCH}(\mathrm{fL})^{\mu}$ & $29.16 \pm 1.17$ & $29.34 \pm 1.22$ & 0.220 \\
\hline Platelet $\left(\times 10^{9} / \mathrm{L}\right)^{\mu}$ & $251.55 \pm 32.5$ & $262.25 \pm 33.7$ & 0.035 \\
\hline
\end{tabular}

${ }^{\mu}:$ mean \pm standard deviation.

ALT: alanine aminotransferase, HDL: High-density lipoprotein, LDL: lowdensity lipoprotein, TSH: thyroid stimulating hormone, ESR: erythrocyte sedimentation rate, $\mathrm{MCV}$ : mean corpuscular volume, $\mathrm{MCH}$ : mean corpuscular hemoglobin.

\section{Discussion}

In the survey stage of the study, the opinions of patients presenting to the outpatient clinics and of the physicians about dietary restrictions before blood tests were similar and fasting state of patients presenting to the blood collection unit was also similar. The $\mathrm{CV}$ were $\leq 5 \%$ for the majority of the parameters examined in the study. This finding suggests high reproducibility (accuracy) of these tests [10]. In the laboratory analysis stage of the study, postprandial glucose $(\mathrm{p}<0.01)$, triglyceride $(\mathrm{p}<0.01)$, and platelet $(\mathrm{p}=0.035)$ values were higher, whereas postprandial sodium $(\mathrm{p}=0.01)$ was found to be lower. These four parameters had a CV below 5\%. No statistically significant difference was found between the fasting and postprandial levels of other parameters.

Postprandial blood samples were collected two hours after meal. The reason for the selection of this time interval is that the American Association of Diabetes recommends blood collection two hours after a meal for oral glucose challenge test and postprandial glucose testing [11]. In addition, insulin secretion which increases after meal and affects carbohydrate and lipid metabolism [12] and intestinal incretins [13] return to baseline values two hours after meal.

Hyperglycemia is associated with two defects in type 2 $\mathrm{DM}$; the first defect is insulin resistance in the liver and muscle tissue and the second defect is the progressive decline in the pancreatic insulin production. Glucose taken in a normal diet is largely $(70 \%)$ used by the muscle tissues. Insulin resistance in the muscle tissues causes postprandial hyperglycemia and impaired glucose tolerance. In the natural course of type $2 \mathrm{DM}$, an individual with insulin resistance and normal glucose tolerance adopts this condition by excessive insulin secretion. Due to increased compensatory insulin secretion initially, insulin resistance is not able to disrupt the glucose uptake by the muscle tissues and to increase hepatic glucose production. Glucose uptake by the muscle tissues is impaired with increasing insulin resistance and the increase in postprandial plasma glucose concentration, then, becomes remarkable. The increase in baseline insulin secretion during this period is sufficient to maintain fasting plasma glucose and hepatic glucose production in normal ranges. However, there is a substantial increase in the postprandial plasma glucose concentration and duration required for elevated glucose levels return to normal. Thus, insulin resistance is further impaired and a compensatory increase in the insulin secretion fails to maintain fasting plasma glucose concentration within normal ranges. This series of pathophysiological disturbances explains why postprandial hyperglycemia occurs many years before fasting hyperglycemia becomes evident [14].

It is well-known that the prevalence of type $2 \mathrm{DM}$ is 12 times higher than that of type 1 diabetes [15]. If type $2 \mathrm{DM}$ is more prevalent in a particular population and if postprandial glucose is first impaired in type 2 DM [16], testing of postprandial glucose concentrations is more important to early diagnose DM.

In addition, triglyceride levels substantially increase after meal. Lipoproteins follow a complex metabolic pathway after meal, as triglycerides found in the structure of very-low density lipoproteins and chylomicrons are processed through the same catabolic pathway. It is, therefore, recommended that 
triglycerides be tested after an overnight fasting to obtain comparable results [17]. In their study, Ferreira et al. [18] administered 900 isocaloric diet to two groups: one group receiving poor-fat content diet and the other receiving high-fat content diet. They found a significant increase in the triglyceride levels at one and three hours in the high-fat group, but no significant increase in the low-fat group. In our study, we also found a significant increase in triglycerides at two hours after meal ( $p=0.06)$. Similarly, Plumelle et al. [19] reported significant increases in both glucose and triglyceride levels.

Several studies have shown that increased fasting triglyceride levels are associated with an increased risk of cardiovascular disease [20, 21]. Of note, atherosclerosis has been suggested to be a postprandial phenomenon [22]. A recent prospective cohort studies have demonstrated a close relationship between postprandial hypertriglyceridemia and coronary heart disease and stroke $[23,24]$. The Women's Health Study found that postprandial triglyceride levels were associated with cardiovascular events independent from other risk factors, lipids, and insulin resistance, whereas fasting triglyceride levels showed a weaker association [23]. In particular, triglyceride levels measured in blood samples collected two to four hours after meal exhibited a stronger correlation. Similarly, in a population study, which published 23-year follow-up results of a total of 103,860 individuals in 2018, postprandial triglyceride levels were found to be associated with the development of heart failure [25].

In the present study, we found no significant difference between fasting and postprandial total cholesterol, low-density lipoprotein (LDL) and high-density lipoprotein (HDL) levels. The study by Ferreira et al. [18] showed no significant difference between the fasting and postprandial HDL and non-HDL measurements at one and three hours after meal. In a free-diet study conducted by Ginsberg et al. [26] in young and non-obese patients, serial measurements showed no significant difference between the fasting and postprandial total cholesterol levels, whereas there was a slight decline in the LDL and HDL levels between two and four hours after meal. Another study demonstrated that both postprandial LDL and fasting LDL levels had a similar prognostic value [27].

The guidelines published until 2009 emphasized only the importance of fasting lipid profile. As of 2009, however, the Danish Society of Clinical Biochemistry recommended that postprandial lipid measurement would be of benefit in predicting cardiovascular risks [4]. This was followed by the report of the American Heart Association (AHA) on triglycerides and cardiovascular diseases in 2011, stating that postprandial triglyceride measurement could be of use [5]. In 2016, the consensus report by the European Society of Cardiology and European Federation of Clinical Chemistry and Laboratory Medicine emphasized the importance of postprandial lipid profile [7]. Finally, in 2017, the joint declaration of the American Association of Clinical Endocrinologists and the American College of Endocrinology stated that postprandial lipid profile was useful in cardiovascular risk prediction [28]. Despite current recommendations, the majority of physicians (77\%) preferred fasting blood tests in the survey stage of the present study.

Furthermore, we found a statistically significant decrease in the postprandial sodium levels in the present study. A statistically significant difference remained even after the correction of sodium levels in patients with blood glucose levels above $125 \mathrm{mg} / \mathrm{dL}$. Sothern et al. [29] investigated the circadian rhythm of sodium in 14 healthy volunteers and found a significant increase in the sodium levels measured in the afternoon. Their results are not consistent with our findings. The $\mathrm{CV}$ for sodium in our laboratory was $1.43 \%$, indicating the reliability of our laboratory. Thus, we need further studies to confirm or rule out whether postprandial hyponatremia occurs.

On the other hand, we found no significant difference between the fasting and postprandial leukocyte, hemoglobin, $\mathrm{MCV}, \mathrm{MCH}$, erythrocyte sedimentation rate, and PT. In a study of 77 patients, Plumelle et al. [19] similarly found no significant difference between fasting and postprandial values of hematological parameters. However, some studies showed a significant increase in the postprandial neutrophil count and a decrease in the lymphocyte and eosinophil count, hemoglobin, and hematocrit levels [30, 31]. Lippi et al. [30] suggested that a decline in hemoglobin and hematocrit levels could be related with postprandial hemodilution.

Moreover, we found a significant increase in the postprandial platelet count than fasting platelet count $(\mathrm{p}<0.035)$. The CV for platelets in our laboratory was $2.1 \%$. This suggests that platelet count in our laboratory has a high reproducibility (accuracy). A study by Wiens et al. [32] reported significantly higher platelet counts at three hours after a high-fat diet. Bremner et al. [33] observed an increase in the platelet count measured in the morning than the platelet count measured in the afternoon. Lippi et al. [30] found a significant decrease in platelet count and attributed this finding to hemodilution. The increase in the platelet count in the present study may be associated with the circadian rhythm, as postprandial blood samples were collected two hours after lunch.

In their study, Plumelle et al. [19] evaluated hormonal parameters in fasting and postprandial blood samples and reported no significant difference in vitamin $\mathrm{D}$, free $\mathrm{T} 3$, free $\mathrm{T} 4$, dehydroepiandrosterone sulfate, follicle-stimulating hormone, luteinizing hormone, and insulin-like growth factor, but a significant difference in the prolactin, adrenocorticotropic hormone, C-peptide, insulin, thyroid-stimulating hormone (TSH), and parathyroid hormone levels. It was found that serum TSH levels showed diurnal variation with postprandial decrease particularly after breakfast. In our study, we were able to analyze only TSH levels and found no significant difference between the fasting and postprandial measurements.

Nonetheless, our study has some limitations. The first limitation is that current results deriving from 22 parameters cannot be generalized to all biochemical and hematological parameters. Second, four of 22 parameters had a CV of higher than 5\%; however, these parameters were eventually included in the statistical analysis. On the other hand, parameters with a CV of higher than $5 \%$ did not show significant difference between the fasting and postprandial measurements.

In conclusion, our study results suggest that postprandial blood collection is convenient for patients, as it allows blood collection at any time of the day. It also reduces the risk of hypoglycemia in patients with DM receiving glucosereducing medications. In addition, the postprandial blood collection allows early diagnosis of diabetes, if the test is performed to screen the patient for diabetes, as postprandial glucose is the first to be impaired in diabetes cases. Also, it avoids dose interruptions in such patients as those with hypertension. Finally, it eases the workload of the laboratory by distributing patients to different hours of the day. With accumulating data, clinicians may be more positive in blood tests in postprandial.

\section{References}

1. Kackov S, Simundic AM, Gatti-Drnic A. Are patients well informed about the fasting requirements for laboratory blood testing? Biochemia medica. 2013;23:326-31. 
2. Adcock DM. Collection, transport, and processing of blood specimens for testing plasma-based coagulation assays and molecular hemostasis assays; approved guideline-fifth edition. January 2008. Available from: https://clsi.org/media/1399/h21a5_sample.pdf

3. Complete blood count (CBC). Mayo Clinic Web site. 2017 [cited 2017 July 20]. Available from: http://www. mayoclinic.org/testsprocedures/complete-blood-count/basics/howyou-prepare/prc20014088.

4. Nordestgaard BG, Hilsted L, Stender S. [Plasma lipids in non-fasting patients and signal values of laboratory results]. Ugeskr Laeger. 2009; 171:1093.

5. Miller M, Stone NJ, Ballantyne C, Bittner V, Criqui MH, Ginsberg HN, et al. Triglycerides and cardiovascular disease: a scientific statement from the American Heart Association. Circulation. 2011;123:2292-333.

6. Rabar S, Harker M, O'Flynn N, Wierzbicki AS. Lipid modification and cardiovascular risk assessment for the primary and secondary prevention of cardiovascular disease: summary of updated NICE guidance. BMJ. 2014:349:94356.

7. Nordestgaard BG, Langsted A, Mora S, Kolovou G, Baum H, Bruckert $\mathrm{E}$, et al. Fasting is not routinely required for determination of a lipid profile: clinical and laboratory implications including flagging at desirable concentration cut-points - a joint consensus statement from the European Atherosclerosis Society and European Federation of Clinical Chemistry and Laboratory Medicine. Eur Heart J. 2016;37:1944-58.

8. [Diler A, Sert S, Aybek H, Yılmaztürk G. Klinik laboratuarlarda toplam laboratuar performansının değerlendirilmesi: Normalize OPSpec Grafikleri, Altı Sigma ve Hasta Test Sonuçları]. Türk Biyokimya Dergisi 2005;30:296-305.

9. Flanagin A, Fontanarosa PB, DeAngelis CD. Authorship for research groups. JAMA. 2002;288:3166-8.

10. Emekli Dİ, Güçlü K, Turna G, İlanbey B, Nar R, Ciçek EA. Klinik Laboratuvarlarda Analitik Süreç Değerlendirilmesi: Altı Sigma Metodolojisi. Türk Klinik Biyokimya Dergisi. 2016;14:79-86.

11. Standards of medical care in diabetes - 2015 abridged for primary care providers. Clin Diabetes. 2015;33:97-111.

12. Masharani U, German M. Pancreatic hormones and diabetes mellitus. In: Gardner DG, Shoback D, editors. Greenspan's basic \& clinical endocrinology. New York: McGraw-Hill; 2011.pp.612-17.

13. Ranganath LR. The entero-insular axis: implications for human metabolism. Clin Chem Lab Med. 2008;46:43-56.

14. Adams SH, Newman JW. Metabolomics: applications in type 2 diabetes mellitus and insulin resistance. In: DeFronzo RA, Ferrannini E, Alberti KGMM, Zimmet P, Alberti G, editors. International Textbook of Diabetes Mellitus. John Wiley \& Sons; 2015.pp.275-82.

15. Nathan DM. Long-term complications of diabetes mellitus. New Eng J Med. 1993;328:1676-85.

16. Leiter LA, Ceriello A, Davidson JA, Hanefeld M, Monnier L, Owens $\mathrm{DR}$, et al. Postprandial glucose regulation: New data and new implications. Clin Ther. 2005;27 Suppl B:S42-S56.

17. Stein EA, Myers GL. National cholesterol education program recommendations for triglycerides measurement: executive summary. The National Cholesterol Education Program Working Group on Lipoprotein Measurement. Clin Chem. 1995;41:1421-6.

18. Ferreira AC, Peter AA, Mendez AJ, Jimenez JJ, Mauro LM, Chirinos JA, et al. Postprandial hypertriglyceridemia increases circulating levels of endothelial cell microparticles. Circulation. 2004;11:3599-603.

19. Plumelle D, Lombard E, Nicolay A, Portugal H. Influence of diet and sample collection time on 77 laboratory tests on healthy adults. Clin Biochem. 2014:47:31-7.

20. Sarwar N, Danesh J, Eiriksdottir G, Sigurdsson G, Wareham N, Bingham S, et al. Triglycerides and the risk of coronary heart disease: 10,158 incident cases among 262,525 participants in 29 Western prospective studies. Circulation. 2007;115:450-8.

21. Patel A, Barzi F, Jamrozik K, Lam TH, Ueshima H, Whitlock G, et al. Serum triglycerides as a risk factor for cardiovascular diseases in the Asia-Pacific region. Circulation. 2004;110:2678-86.

22. Kolovou GD, Anagnostopoulou KK, Daskalopoulou SS, Mikhailidis DP, Cokkinos DV. Clinical relevance of postprandial lipaemia. Curr Med Chem. 2005;12:1931-45.

23. Bansal S, Buring JE, Rifai N, Mora S, Sacks FM, Ridker PM. Fasting compared with nonfasting triglycerides and risk of cardiovascular events in women. JAMA. 2007;298:309-16.

24. Freiberg JJ, Tybjaerg-Hansen A, Jensen JS, Nordestgaard BG Nonfasting triglycerides and risk of ischemic stroke in the general population. JAMA. 2008;300:2142-52.
25. Varbo A, Nordestgaard BG. Nonfasting Triglycerides, Low-Density Lipoprotein Cholesterol, and Heart Failure Risk: Two Cohort Studies of 113554 Individuals. Arterioscler Thromb Vasc Biol. 2018;38:464-72.

26. Ginsberg HN, Karmally W, Siddiqui M, Holleran S, Tall AR, Rumsey $\mathrm{SC}$, et al. A dose-response study of the effects of dietary cholesterol on fasting and postprandial lipid and lipoprotein metabolism in healthy young men. Arterioscler Thromb. 1994;14:576-86.

27. Doran B, Guo Y, Xu J, Weintraub H, Mora S, Maron DJ, et al Prognostic value of fasting versus nonfasting low-density lipoprotein cholesterol levels on long-term mortality: insight from the National Health and Nutrition Examination Survey III (NHANES-III) Circulation. 2014;130:546-53.

28. Jellinger PS, Handelsman Y, Rosenblit PD, Bloomgarden ZT, Fonseca VA, Garber AJ, et al. American Association of Clinical Endocrinologists and American College of Endocrinology guidelines for management of dyslipidemia and prevention of cardiovascular disease. Endocr Pract. 2017;23 Suppl 2:1-87.

29. Sothern RB, Vesely DL, Kanabrocki EL, Bremner FW, Third JL, McCormick JB, et al. Circadian relationships between circulating atrial natriuretic peptides and serum sodium and chloride in healthy humans. Am J Nephrol. 1996;16:462-70.

30. Lippi G, Lima-Oliveira G, Salvagno GL, Montagnana M, Gelati M, Picheth G, et al. Influence of a light meal on routine haematological tests. Blood Transfus. 2010;8:94-9.

31. Van Oostrom A, Sijmonsma T, Rabelink T, Van Asbeck B, Cabezas MC. Postprandial leukocyte increase in healthy subjects. Metabolism. 2003;52:199-202.

32. Wiens L, Lutze G, Luley C, Westphal S. Platelet count and platelet activation: impact of a fat meal and day time. Platelets. 2007;18:171-3.

33. Bremner WF, Sothern RB, Kanabrocki EL, Ryan M, McCormick JB, Dawson S, et al. Relation between circadian patterns in levels of circulating lipoprotein(a), fibrinogen, platelets, and related lipid variables in men. Am Heart J. 2000;139:164-73. dicitis. Pediatr Int. 2016;58:202-5. 